\title{
The determinants of off-budget activity of state and local governments*
}

\author{
MICHAEL L. MARLOW \\ Department of Economics, California Polytechnic State University, San Luis Obispo, CA \\ 93407
}

DAVID JOULFAIAN

Office of Tax Analysis, U.S. Department of Treasury, Washington, DC 20220

\section{Introduction}

The study of government growth is one of the fastest growing research areas in public choice. Public sector growth appears to be universal at all levels of government as shown by a rich data set that permits the testing of a large number of hypotheses. Many competing and complementary hypotheses have been offered to explain public sector growth. ${ }^{1}$ Following the 1970s "taxpayer revolts," many studies have examined the abilities of various constraints to control the public sector size and, more specifically, government spending. ${ }^{2}$

As the hypotheses and tests become more sophisticated, the importance of another research area has become increasingly evident: an appropriate measure of public participation in the economy is quite elusive. While important, government employment data and simple government expenditure-to-GNP ratios are incomplete measures of government size. Not only are governments financed by many sources (legislated taxes, inflation-related taxes, grants, debt-issue and off-budget receipts), but also many areas of government activity elude simple measurement (regulations, resource allocation via subsidy, and legislation). Clearly, the issue of measurement is important for understanding the public sector as well as the ability to empirically test relevant hypotheses.

This paper examines an often-overlooked, or well-hidden, facet of the public sector. It examines the "off-budget" sectors' relation to other less-hidden facets of the public sector. Bennett and DiLorenzo (1982) is the seminal work in this area. Arguing that local governments evade tax- and expenditurelimitations by placing vast amounts of expenditures off-budget, Bennett and DiLorenzo provide two important pieces of information in the study of the

* The valuable comments of a referee are appreciated. The views expressed are those of the authors alone and do not necessarily represent those of the U.S. Department of Treasury. 
public sector. One, their evidence demonstrates that off-budget activity is an important dimension in public sector size. Two, it suggests that total government spending is influenced by relative prices and constraints on politicians.

That total government spending is influenced by relative prices and political constraints is the primary thesis of this paper. By treating the off-budget activities of state and local governments as one form of public participation in the economy, we model the interrelations between governments' off-budget and on-budget activities to explain the choice of total budgetary allocations by state and local governments. After focusing on the relative substitutability of onand off-budget activities and controlling for the effects of various supply-side factors (federal grants, tax- and expenditure-limitations, debt-issue), the results suggest that the size of governments' off-budget activity is strongly influenced by its on-budget spending. That is, "big" on-budget spenders tend to be "big" off-budget spenders as well.

\section{Existing literature on government size}

The traditional literature on government size generally measures public sector activity as on-budget spending relative to income, or population. ${ }^{3}$ However, it is commonly known that government participation in an economy extends far beyond its expenditures. These "non-expenditure" items include tariffs, offbudget items, subsidies, entry barriers, minimum wage laws, rent-controls, mortgage interest deductions, tax credits, equal opportunity laws, legal drinking ages, and so forth. While all these non-expenditure items reflect a large and diverse array of sometimes-conflicting, sometimes-consistent goals of government policy, they all affect resource allocations. Consequently, traditional measures of government size represent underestimates of the true impact of the public sector on resource allocation and this measurement problem inevitably pervades all empirical studies by introducing measurement error. ${ }^{4}$

The available evidence on heretofore "hidden" government offers valuable information on the extent of total public participation in the economy. Bennett and DiLorenzo (1982) provide a painstaking study of one effective means of circumventing taxpayer-control over government spending: off-budget enterprises. The fact that debts, expenditures, and additional revenues are not necessarily approved by voters creates an incentive for politicians to go off-budget. The argument is made that recent "tax-revolts" and enactments of tax- and spend-limitations are not perfectly effective in exerting fiscal discipline on governments. By placing billions of dollars off-budget, Bennett and DiLorenzo document extensive circumvention of existing tax- and expenditure-limitations. Evidence in support of the notion that state and local governments circumvent intent of tax-and expenditure-limitations can be found in Bails (1982) 
and Abrams and Dougan (1986). At the federal level, Marlow and Manage (1987) argue that the existence of national debt ceilings have not stopped Congress from approving higher ceilings whenever they become binding. Moreover, the use of off-budget spending at the federal level has grown rapidly over the past ten years.

An interesting attempt at providing a more comprehensive measure of government is the focus of Shughart and Tollison (1986) which measures government size as the legislative output of the U.S. Congress. Examples of legislative output are numbers of bills introduced, length of session and bills passed per legislator. While there are obvious problems of data interpretation, the advantage of this approach is that the data represent the legislation behind all facets of government participation and represents one alternative for measuring government size. ${ }^{5}$

\section{Model of off-budget behavior}

One recurrent proposition in past research is that the growth of some specified governmental activity is primarily due to one causal factor. Buchanan and Wagner (1978) focus on fiscal illusion as the primary cause of public budget deficits. ${ }^{6}$ Bennett and DiLorenzo (1982) focus on political circumvention of tax- and expenditure-limitations via off-budget enterprises as the causal explanation of growth in off-budget activities. Friedman (1978) has argued that the political gains from taxing through inflation preclude the federal government from eliminating inflation. Manage and Marlow (1986) argue that past tax increases may explain government growth.

While all the above hypotheses may contain essential elements of empirical support, a common factor is some notion of the relative costs of funding total government activity. In this sense, we are mainly concerned with supply-related government activity.

We have already outlined the various forms of public activity: on- and offbudget spending, regulations, laws and so forth. The corresponding forms of finance include legislated taxes, inflation-related taxes, federal grants to state and local governments, debt-issue, and off-budget subsidization, taxation, and fees. Two factors determine the vital characteristics of the funding constraint. One, the relative costs of these various funding sources. To finance a given level of public activity, economic theory suggests that governments will utilize relatively cheaper funding sources. That is, optimal usage of funding parameters depends on the relative costs of all sources: legislated taxes, debt-issue, off-budget revenues, grants, etc.

$T w o$, the relative costs of the funding sources are affected by supply-side factors. Three examples follow which suggest that changes in the relative costs of 
funding affect the way in which government is financed and the way in which it grows. Bennett and DiLorenzo argue that the tax revolt resulted in an increase in tax- and expenditure-limitations which, by raising the costs of "going on-budget," resulted in increased use of off-budget activities. Buchanan and Wagner argue that when politicians or the citizenry lowered the resistance to deficit-finance, more spending was financed by debt-issuance (and less through taxation) which ultimately resulted in more government via higher fiscal illusion. Manage and Marlow argue that the recent outcry against deficits may be the result of an increase in the relative cost of financing spending growth through debt-issue. These three examples suggest that institutional supply-side considerations such as tax- and expenditure-limitations and balanced budget rules may affect the relative costs of funding and consequently the size and composition of public sectors.

Formally, we hypothesize that the size of off-budget activity is related to the demand for total government activity and the relative costs of the different forms of funding. Specifically, we model the size of off-budget activity by state and local governments as:

$$
\begin{array}{ll}
\text { OFF } & =\mathrm{f}(\mathrm{ON}, \text { GRANTS, TEL, DEBT, GON }) \\
\text { where OFF } & =\text { size of off-budget activities } \\
\text { ON } & =\text { size of on-budget activities } \\
\text { GRANTS } & =\text { size of grants } \\
\text { TEL } & =\text { tax- and expenditure-limit dummy } \\
\text { DEBT } & =\text { size of debt-issue } \\
\text { GON } & =\text { change in on-budget activities over time. }
\end{array}
$$

ON is defined as total government expenditures relative to the gross state product and, in a second specification, relative to per capita expenditures. The regressions were also estimated using expenditures net of public utility and liquor store expenditures, but since the results are not affected they are not reported here.

Since we assume that politicians do not have non-cost-related preferences for how they finance government activities, $\mathrm{ON}$ is one way to measure the demand for government. That is, it measures the government-bias in a state. States with large ONs are assumed to prefer a relatively large total government sector. Because of our assumption that politicians do not have a non-costrelated preference for on- vs. off-budget activity, the same demand-related determinants of government (median income, population and its density, education ...) should be contained in this variable that would influence OFF and therefore we avoid potential multicollinearity problems between $\mathrm{ON}$ and relevant demand-related variables.

To the extent that federal grants reduce the price of total state and local 
government activities larger GRANTS, defined as the ratio of federal grants to state and local revenues, should be associated with reduced need to "hide" on-budget activities and results in lower off-budget activities. Evidence that grants to sub-federal governments reduce that tax-price perception is found in Winer (1983) and Logan (1986).

In states where legislatures have a strong preference for large government, the presence of limits on government expenditures TEL is expected to lead to an expansion of off-budget activity. Following the Bennett and DiLorenzo argument that growth in off-budget activity is related to tax- and expenditurelaws, we use a dummy variable for the nineteen states that had nominal tax and expenditure limitations in effect in 1984. Following the Misiolek and Elder (1988) criteria, we define TEL $=1$ for states with tax- and expenditure-laws and TEL $=0$ otherwise. ${ }^{7}$ While Misiolek and Elder report that tax- and expenditure-limitations have exerted significant influences on public budgets, Abrams and Dougan (1986) find no such effect. For those who believe that taxand expenditure-laws are not effective in controling public budgets, TEL should not exert a statistically significant effect on OFF. A positive sign should be hypothesized for those who believe the Bennett and DiLorenzo argument that tax- and expenditure-limitations lead to greater off-budget activity.

Debt-financing, by creating the fiscal illusion of low tax burden, is expected to reduce the need to "hide" on-budget activities. Therefore, DEBT, defined as the ratio of outstanding debt to total revenue, is expected to exert a negative effect on the size of off-budget activities. ${ }^{8}$

Finally, we also consider the effects of growth of on-budget activities on the size of off-budget activities. We hypothesize that states experiencing the strongest growth in on-budget expenditures GON have a greater need to expand the size of OFF. Assuming no change in the relative cost burden of off-budget financing total government vis-a-vis other means of financing, faster growth in total financing needs should be associated with greater usage of off-budget financing. ${ }^{9}$ Given available data, we define GON as the growth of on-budget state and local government expenditures over a six-year period (1979-1984).

Table 1 displays summary statistics for selected variables.

\section{Results}

Two specifications of (1) are estimated. Government expenditures (ON, GON) are normalized by population (per capita) and by the gross state product (GSP). Our measure of OFF, also normalized by population and GSP, is the gross state product of state and local government enterprises (GSPGE). GSPGE is the expenditure variable and is the sum of the earnings, subsidies, plus the surpluses or deficits of such establishments. ${ }^{10}$ This measure is identical to the value of the output of these establishments which represents oper- 
Table 1. Summary statistics of selected variables

\begin{tabular}{lllll}
\hline & \multicolumn{2}{l}{ Normalized by population } & \\
\cline { 2 - 5 } & Off & On & Grants & Debt \\
\hline Mean & 1180.57 & 2261.56 & 0.15 & 0.83 \\
Std. dev & 194.56 & 455.94 & 0.03 & 0.24 \\
Min & 878.99 & 1560.08 & 0.10 & 0.43 \\
Max & 1867.45 & 4113.84 & 0.22 & 1.55 \\
& & & & \\
\hline & Normalized by GSP & & & \\
\cline { 2 - 5 } & Off & On & Grants & Debt \\
\hline Mean & 0.08 & 0.15 & 0.15 & 0.83 \\
Std. dev. & 0.01 & 0.02 & 0.03 & 0.24 \\
Min & 0.06 & 0.11 & 0.10 & 0.43 \\
Max & 0.10 & 0.19 & 0.22 & 1.55 \\
\hline
\end{tabular}

ating and capital expenses, including interest expenses on outstanding debt. The enterprises encompass power, electric, gas, water and sewage, transportation, highways, and lotteries.

We estimate using OLS the two specifications of (1) on 1984 data for all states excluding Alaska. Scheduled Department of Commerce revisions of national income and product accounts preempts us from using more recent data. Preliminary work suggests that, while the results do not change with its inclusion, Alaska is an outlier. Data on gross state product, including that of state and local government enterprises, are obtained from the U.S. Department of Commerce (1988); state and local expenditures, revenues, grants, and outstanding debt in 1984 from the U.S. Department of Commerce (1985b); state and local government expenditures in 1979 from the U.S. Department of Commerce (1980); and population from the U.S. Department of Commerce (1987).

Table 2 displays the regression results for the model normalized by population. Due to potential multicollinearity problems between the various supplyrelated factors, we have included ON and GRANTS in all equations, but isolated out the separate effects of TEL, DEBT and GON by not including them together in the same equation. In other estimations, we have run various other specifications with including all or some subset together in the same equations. To conserve space, we have not included them her since in most cases the results do not change. The only case in which there appears to be significant multicollinearity is between ON and GON. Because of simple correlations between these two variables of approximately -0.82 ( -0.65 when normalized by GSP), we have chosen to display the effects of GON in two ways: by itself and with 
Table 2. Off-budget regressions $\mathrm{s}^{\mathrm{a}}$ - (normalized by population)

\begin{tabular}{lrrrrrrr}
\hline Constant & 1.77 & 0.74 & 0.75 & 0.75 & 0.75 & 0.81 & 1.07 \\
& 12.02 & 8.06 & 8.00 & 13.46 & 7.71 & 8.45 & 10.82 \\
GRANTS & -3.77 & -2.34 & -2.39 & & -2.34 & -2.45 & \\
& 4.04 & 5.84 & 5.80 & & 5.76 & 6.23 & \\
ON & & 0.32 & 0.32 & & 0.32 & 0.33 & \\
& & 14.92 & 14.81 & & 7.63 & 15.42 & \\
TEL & & & -0.01 & & & & \\
& & & 0.60 & & & & \\
GON & & & & 0.48 & 0.01 & & \\
& & & & 8.32 & .10 & & \\
DEBT & & & & & & -0.08 & 0.13 \\
& & & & & & 1.92 & 1.14 \\
$\bar{R}^{2}$ & .24 & .87 & .87 & 0.59 & 0.86 & 0.87 & .01 \\
F & 16.36 & 158.02 & 103.99 & 69.19 & 103.09 & 112.76 & 1.30 \\
n & 49 & 49 & 49 & 49 & 49 & 49 & 49 \\
s.e.e. & .17 & .07 & .07 & .15 & .07 & .07 & .20 \\
\hline
\end{tabular}

a $t$-statistics below estimated coefficients.

ON. This strong collinearity suggests that the size of the public sector has grown more rapidly in those states that exhibit relatively low levels of $O N$. A similar problem, albeit much weaker, exists between ON and DEBT and therefore we have displayed the effect of DEBT in two ways as well.

The results are generally consistent with our expectations. The estimated coefficient on $\mathrm{ON}$ is always positive and highly statistically significant. The coefficients on GRANTS are always statistically significant and of the hypothesized negative sign. As hypothesized, the coefficient on DEBT is negative and statistically significant. When run by itself, the growth of total expenditures GON is found to be positively related to OFF. However, in the presence of $\mathrm{ON}$, it is found to not exert a significant effect on OFF. Because of the high negative collinearity between $\mathrm{ON}$ and GON, it would appear that they are measuring the same basic piece of information: governments with relatively large expenditures as well as governments with rapid growth in expenditures tend to have larger values of OFF. As such, this is evidence in support of the Bennett and DiLorenzo hypothesis that OFF is positively related to past onbudget growth.

The lack of statistical significance on TEL suggests that tax- and expenditure-limitations do not affect off-budget activity. While some may argue that this finding suggests that the Bennett and DiLorenzo hypothesis is not valid, 


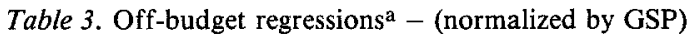

\begin{tabular}{|c|c|c|c|c|c|c|c|}
\hline \multirow[t]{2}{*}{ Constant } & 0.09 & 0.05 & 0.05 & 0.07 & 0.05 & 0.05 & 0.07 \\
\hline & 12.31 & 6.74 & 6.65 & 13.31 & 7.09 & 6.96 & 16.44 \\
\hline \multirow[t]{2}{*}{ GRANTS } & -0.08 & -0.10 & -0.10 & & -0.11 & -0.11 & \\
\hline & 1.77 & 3.37 & 3.27 & & 3.66 & 3.66 & \\
\hline \multirow[t]{2}{*}{ ON } & & 0.29 & 0.29 & & 0.30 & 0.30 & \\
\hline & & 8.73 & 8.50 & & 8.82 & 8.82 & \\
\hline TEL & & & -0.0002 & & & & \\
\hline \multirow[t]{2}{*}{ GON } & & & & 0.25 & -0.15 & & \\
\hline & & & & 3.19 & 2.24 & & \\
\hline \multirow[t]{2}{*}{ DEBT } & & & & & & -0.005 & 0.0065 \\
\hline & & & & & & 1.46 & 1.27 \\
\hline$\overline{\mathbf{R}}^{2}$ & .04 & .63 & .62 & .16 & .66 & .64 & .01 \\
\hline $\mathrm{F}$ & 3.14 & 42.17 & 27.52 & 10.18 & 32.24 & 29.52 & 1.61 \\
\hline $\mathrm{n}$ & 49 & 49 & 49 & 49 & 49 & 49 & 49 \\
\hline s.e.e. & .0087 & .0054 & .0054 & .0081 & .0052 & .0053 & .0088 \\
\hline
\end{tabular}

a $t$-statistics below estimated coefficient.

we argue that a more valid test of their hypothesis would be to consider the relation between TEL and total government activity since OFF is only one avenue for a change caused by TEL to appear. Our finding that TEL is not statistically significant may suggest three possibilities: (1) that tax- and expenditurelimitations do not affect off-budget activity (2) that the effects of such limitations manifest themselves somewhere else in the financing of the public sector or (3) cross-sectional studies may not be suitable for testing the significance of TEL. With respect to the third, unless one assumes that the cross-sectional data represents steady-state reactions to TEL, it may be difficult, if not impossible, to interpret the coefficient on TEL in a simple cross-sectional framework. Taxand expenditure-limitations may be weak or ineffective in any event.

Table 3 displays the results for data normalized by GSP. While, based on $\overline{\mathbf{R}}^{2}$ - and F-statistic criteria, the equation as a whole is less significant than the previous one, the overall ability of the equations to explain off-budget activity remains very high. The only major differences associated with the different normalization are (1) that GON's coefficient is statistically significant and positive when included by itself and turns significant and negative when it is included with ON and (2) the debt variable DEBT loses its statistical significance.

In sum, support for three hypotheses is found. One, on-budget activity is a strong positive determinant of off-budget activity. Two, GRANTS is found to 
exert significant negative effects on off-budget activity. Three, within our cross-sectional framework, tax- and expenditure-limitations are not found to exert significant effects on off-budget activity. However, as noted above, this framework may not be appropriate for the testing for the permanent effect of TEL on off-budget activity.

Not withstanding the above results, a caveat common to all comparative cross-sectional studies of government budgets needs to be mentioned. Given their historical and cultural backgrounds as well as the stages of economic development, the possibilities for going off-budget may have been long exhausted in some states. This problem, of course could have been far worse had we used time series data where the size of off-budget activities is stationary in some states and varies in others.

\section{Conclusion}

The primary finding of this paper is that the off-budget activity of the public sector is significantly and positively related to on-budget activity by state and local governments. We suggest the following policy implications. One, there appears to be evidence that the composition of total government activity is related to the relative costs of the alternative avenues of providing governmental activity. Future research into determining the nature of the relative cost differences may be one useful means of understanding both the composition of government activity as well as its total size. Two, our ability to measure the "true" size of public sector participation in the economy must go well beyond our attempt here. While we have presented information on one of the important "hidden" elements of public sector participation, we are still a long way from effectively incorporating similar data on legislation, regulations and so forth into our empirical tests. Further research into these issues is clearly warranted.

\section{Notes}

1. For example, Wagner's law (Wagner, 1893), special interest group formations (Olson, 1982), bureaucratic monopoly power (Niskanen, 1971), rent-seeking activity (Weede, 1984), fiscal illusion (Buchanan and Wagner, 1978), crises (Higgs, 1985), legislator specialization (Crain, Tollison, Goff and Carlson, 1985), extending voting franchises (Meltzer and Richards, 1983), and the demand for protection (Bordo and Landau, 1987).

2. Buchanan and Flowers (1969) is an early study setting the stage for the tax revolt. Studies that question the effectiveness of various tax limitations on government are Bennett and DiLorenzo (1982), Bails (1982), Toma and Toma (1983), Stein, Hamm and Freeman (1983), Abrams and Dougan (1986) and Marlow and Orzechowski (1988).

3. See, for example, Nutter (1978) or Marlow (1986) for traditional measures of government size. 
4. See Bennett and Johnson (1980) for a discussion of problems related to the estimation of the size of the public sector.

5. One problem with using these data for empirical testing of hypotheses is the necessity of simple-summing all legislative input. That is, it is not clear what relative weights one should attach to dissimilar activities. For example, enactment of a new regulatory agency for consumer matters is potentially more participatory than introduction of a new name for some existing Commission, or legislation calling for "National Pickle Week."

6. More precisely, Buchanan and Wagner (1978) argue that a growing Keynesian bias toward deficit finance and the political affinity of spending without taxing are causal elements behind growing use of deficit finance.

7. The nineteen states are: Alaska, Arizona, California, Colorado, Hawaii, Idaho, Louisiana, Michigan, Missouri, Montana, Nevada, New Jersey, Oregon, Rhode Island, South Carolina, Tennessee, Texas, Utah, and Washington. Note, however, that we have excluded Alaska from our example.

8. A related hypothesis is that structure and complexity of tax systems is one way to create fiscal illusion. For studies of this hypothesis, see Wagner (1976), Pommerehne and Schneider (1978), Breeden and Hunter (1985), and Feenberg and Rosen (1987).

9. That is, our model assumes a constant relative cost of financing total government via offbudget finance. A more complex model might assume that the relative cost perception by the public might be linear up to some threshold and rise quickly thereafter. See Marlow (1988) for a similar point in the area of taxpayer-perceived prices of deficit finance.

10. For further detail, see U.S. Department of Commerce (1985a).

\section{References}

Abrams, B.A. and Dougan (1986). The effects of constitutional constraints on governmental spending. Public Choice 49: 101-116.

Bails, D. (1982). A critique of the effectiveness of tax-expenditure limitations. Public Choice 38: 129-138.

Bennett, J.T. and Johnson, M.H. (1980). The political ecocomy of federal government growth: 1959-1978. College Station, TX: Center for Education and Research in Free Enterprise.

Bennett, J.T. and DiLorenzo, T.J. (1982). Off-budget activities of local government: The bane of the tax revolt. Public Choice 39: 333-342.

Bordo, M.D. and Landau, D. (1987). The growth of government: A protection explanation. Public Choice 53: 167-174.

Buchanan, J.M. and Flowers, M. (1969). An analytic setting for a 'taxpayers' revolution. Western Economic Journal 8: 349-359.

Buchanan, J.M. and Wagner, R.E. (1977). Democracy in deficit: The political legacy of Lord Keynes. New York: Academic Press.

Breeden, C.H. and Hunter, W.J. (1985). Tax revenue and tax structure. Public Finance Quarterly 13 (April): 216-224.

Crain, W.M., Tollison, R.D., Goff, B.L. and Carlson, D. (1985). Legislator specialization and the size of government. Public Choice 46: 311-315.

Feenberg, D.R. and Rosen, H.S. (1987). Tax structure and public sector growth. Journal of Public Economics 32: 185-201.

Friedman, M. (1978). Tax limitation, inflation and the role of government. Dallas: The Fisher Institute.

Higgs, R.R. (1985). Crises, bigger government and ideological change. Explorations in Economic History 22: 1-28. 
Logan, R.R. (1986). Fiscal illusion and the grantor government. Journal of Political Economy 96: 1304-1318.

Manage, N. and Marlow, M.L. (1986). The causal relation between federal expenditures and receipts. Southern Economic Journal 52: 617-629.

Marlow, M.L. (1986). Private sector shrinkage and the growth of industrialized economies. Public Choice 49: 143-154.

Marlow, M.L. and Manage, N. (1987). Expenditures and receipts: Testing for causality in state and local government finances. Public Choice 53: 253-255.

Marlow, M.L. and Orzechowski, W. (1988). Controlling Leviathan through tax reduction. Public Choice 58: 237-246.

Marlow, M.L. (1988). Political incentives, balanced budget rules and the size of government. Presented at the 1988 public choice meetings in San Francisco, CA.

Meltzer, A.H. and Richards, S.F. (1983). Tests of a rational theory of government. Public Choice 41: 403-418.

Misiolek, W.S. and Elder, H.W. (1988). Tax structure and the size of government: An empirical analysis of the fiscal illusion and fiscal stress arguments. Public Choice 57: 233-247.

Niskanen, W.A. (1971). Bureaucracy and representative government. Chicago: Aldine-Atherton.

Nutter, G.W. (1978). Growth of government in the west. Washington, DC: American Enterprise Institute.

Olson, M. (1982). The rise and decline of nations. New Haven: Yale University Press.

Pommerehne, W.W. and Schneider, F. (1978). Fiscal illusion, political institutions, and local public spending. Kyklos 31: 381-408.

Shughart, W.F. and Tollison, R.D. (1986). On the growth of government and the political economy of legislation. Research in Law and Economics 9: 111-127.

Stein, R.M., Hamm, K.E. and Freeman, P.K. (1983). An analysis of support for tax limitation referenda. Public Choice 40: 187-194.

Toma, M. and Toma, E.F. (1980). Bureaucratic response to tax limitation amendments. Public Choice 35: 333-348.

U.S. Department of Commerce. (1980, October). Bureau of the Census, Governmental finances in 1978-1979.

U.S. Department of Commerce. (1985a). BEA Staff Paper 42, Experimental estimates of gross state product by industry.

U.S. Department of Commerce. (1985b). Bureau of the Census, Governmental finances in $1983-1984$.

U.S. Department of Commerce. (1987, December). Bureau of the Census, Statistical abstract of the United States 1988.

U.S. Department of Commerce. (1988, May). Bureau of Economic Analysis, Survey of current business.

Wagner, A. (1893). Grundlegung der politischen Ökonomie. Leipzig.

Weede, E. (1984). Democracy, creeping socialism, and ideological socialism in rent-seeking societies. Public Choice 44: 349-365.

Winer, S.L. (1983). Some evidence on the effect of the separation of spending and taxing decisions. Journal of Political Economy 91: 126-140. 